FOLIA POMERANAE UNIVERSITATIS TECHNOLOGIAE STETINENSIS

Folia Pomer. Univ. Technol. Stetin., Oeconomica 2018, 347(93)4, 77-86

\title{
RADY UCZELNI JAKO NOWY ORGAN WŁADZY W SZKOŁACH WYŻSZYCH. PRZYKŁAD NIEMIEC
}

\section{UNIVERSITY COUNCILS AS NEW AUTHORITIES IN HIGHER EDUCATION. GERMAN EXAMPLE}

Katedra Analizy Systemowej i Finansów, Zachodniopomorski Uniwersytet Technologiczny w Szczecinie, ul. Klemensa Janickiego 31, 71-270 Szczecin, ORCID: 0000-0001-6284-723x e-mail: feliks.stawarczyk@zut.edu.pl

\begin{abstract}
Summary. University councils have been additional authorities in higher education in Germany for 20 years. University council members regard the role of university councils as retriever of extermal expertise, supporter in the development of strategic objectives and partner for the strengthening of the ability of reform. The article treats how they fulfil their role and achieve their goals.
\end{abstract}

Słowa kluczowe: New Public Management, rady uczelni, reforma szkolnictwa wyższego. Key words: Univeristy councils, New Public Management, heigher educations reform.

\section{WSTĘP}

Przed dwudziestu kilku laty zapoczątkowane zostały w Niemczech reformy związane z przyjęciem nowego paradygmatu w zarządzaniu instytucjami publicznymi pod nazwą New Public Management (NPM) (Münch 2011). Reforma ta objęła także szkolnictwo wyższe. Miało to na celu zastąpienie dotychczasowego zbiurokratyzowanego państwowego systemu administrowania szkołami wyższymi przez system zarządzania zorientowany na osiąganie wyników w zakresie wyższej jakości badań i dydaktyki oraz konkurencyjności między uczelniami (Schröter 2011). System ten miał też przyczynić się, w szerszym zakresie niż dotychczas, do otwarcia na gospodarkę i społeczeństwo.

W postulowanych ramach szkoły wyższe, a właściwie kierujący nimi, otrzymaliby znacznie większe możliwości samodzielnego działania, ale też ciążyłaby na nich znaczna odpowiedzialność za podejmowane decyzje. Wprowadzenie rad do szkół wyższych jest częścią reformy, która stanowi krok pomiędzy biurokratyczno-oligarchicznym modelem kierowania szkolnictwem wyższym a modelem menedżerskim.

Zmiany legislacyjne w Niemczech w 1998 r. przeniosły nadzór państwa nad szkołami wyższymi na poziom krajów związkowych. Rady uniwersyteckie, w ogólnych założeniach reformy, opierają się na dwóch filarach. Z jednej strony, powinny pośredniczyć pomiędzy władzami kraju związkowego a kierownictwem uczelni, w szczególności w uzgadnianiu celów ogólnospołecznych. Z drugiej zaś strony, powinny stanowić nowy organ władzy, sprawujący nadzór nad szkołą wyższą. 
Instrumenty, jakimi posługują się w swojej pracy rady szkół wyższych, są jeszcze stosunkowo słabo zbadane. Jak swoją funkcję pełnią rady uczelni i czy rzeczywiście spełniły pokładane w nich nadzieje i oczekiwania - tego dotyczy niniejszy artykuł. Temat jest szczególnie aktualny w kontekście wprowadzania w szkołach wyższych w Polsce rad uczelni, instytucji dotychczas nieznanych w naszym kraju.

\section{GENEZA I ADAPTACJA IDEI RAD SZKÓŁ WYŻSZYCH}

Pojęcie i koncepcja rad uczelni pochodzi z obszaru prywatnej gospodarki, gdzie w spółkach kapitałowych występują rady nadzorcze. Instytucja rady na uniwersytetach ma szczególnie, długą tradycję w amerykańskim systemie szkolnictwa wyższego (Lange 2010).

Po raz pierwszy powołano ją w 1642 r. w College w Harwardzie jako gremium nadzorcze, w skład którego weszli członkowie pochodzący spoza szkoły wyższej. Po drugiej wojnie światowej, w latach 1947-1948, brytyjskie władze, rezydujące w Niemczech, przygotowując reformę szkolnictwa wyższego w swojej strefie okupacyjnej, przewidywały funkcjonowanie rad jako organów władzy w uczelniach. Ostatecznie jednak nie doszło do realizacji tego pomysłu. W tradycji niemieckich szkół wyższych nie występowały rady. Jako nowy organ władzy (obok senatu i rektora) w zarządzaniu szkołami wyższymi w Niemczech rady uczelniane zostały ustanowione nowelizacją ustawy regulującej organizację szkolnictwa wyższego krajów związkowych (landów) w 1998 roku (Behm 2010). Tym samym nastąpiło przekazanie landom większej autonomii w organizacji szkolnictwa wyższego.

Wprowadzanie rad w uczelniach następowało w rezultacie wdrażanej w latach 90. ub.w. reformy szkolnictwa wyższego, inspirowanej zmianą paradygmatu zarządzania poprzez koncepcję New Public Management (NPM). Przy czym należy zauważyć, że idea rad jest w istocie starsza od NPM. Celem zmian było wzmocnienie autonomii szkół wyższych i ukierunkowanie ich na wzmożoną wzajemną konkurencję. W następstwie państwo wycofywało się z bezpośredniego kierowania szkołami wyższymi. Kompetencje i zadania, które wcześniej należały do ministerstwa szkolnictwa wyższego, przechodziły stopniowo w ręce rad uczelni. Ponadto zadanie rad miało polegać na wzmocnieniu bezpośrednich kontaktów z interesariuszami zewnętrznymi i na trosce o to, aby szkoły wyższe nie traciły $z$ pola widzenia potrzeb społeczeństwa.

Jako pierwowzór dobrych praktyk w tym zakresie w politycznej debacie w Niemczech brano pod uwagę doświadczenia wynikające z funkcjonowania rad na amerykańskich uniwersytetach oraz w Szwajcarii. Jednakże niemiecka debata publiczna dotycząca możliwości i kompetencji rad, które miały zaistnieć w uczelniach, była bardziej zorientowana na system gospodarczy niż na zagraniczne wzorce (Lange 2010).

Nowelizacje ustaw o szkolnictwie wyższym w poszczególnych niemieckich landach następowały w zróżnicowanym tempie. Pierwsze rady wprowadzono w szkołach wyższych w Bawarii i Badenii-Wirtembergii po 1998 r. (Bogumil 2007). Ostatnim krajem związkowym, który wdrożył w życie ustawę umożliwiającą tworzenie rad szkół wyższych na swoim terenie (nastąpiło to dopiero 1 stycznia 2007 r.), była Nadrenia Północna-Westfalia. Rady wprowadzono w 15 landach jako kolegialne organy w prawie wszystkich dużych, średnich i małych szkołach wyższych - na uniwersytetach, w wyższych szkołach technicznych, pedagogicznych 
i artystycznych. Wyjątek stanowi Brema - kraj związkowy, w którymi nie istnieje prawny obowiązek powoływania rad na uczelniach. Rady w szkołach wyższych są zasadniczo uksztaltowane przez ustawy danego kraju związkowego i nie podlegają żadnym bezpośrednim oddziaływaniom ze strony państwa. Nie istnieje w związku z tym jeden ogólny niemiecki model rady uczelni ani ustalony powszechnie obwiązujący zakres praw i obowiązków. Rola, zadania i kompetencje rad uczelnianych, przyjęte w ustawach o szkolnictwie wyższym w poszczególnych landach, są mocno zróżnicowane.

Szczególny przypadek rozwiązań prawnych w tym zakresie dotyczy Brandenburgii, gdzie żadna szkoła wyższa nie ma własnej rady. Zamiast tego istnieje jedna krajowa rada dla wszystkich uczelni tego landu. Podobne rozwiązanie początkowo dotyczyło Schlezwiku-Holsztyn, gdzie powołano wspólną radę dla trzech uniwersytetów: we Flensburgu, w Kilonii i Lubece. Jednakże w 2013 roku nastąpiło rozwiązanie wspólnej rady uniwersyteckiej i każda z uczelni powołała swój własny organ nadzorczy. Decentralizacja, w zakresie poszukiwania optymalnych dla danego landu, rozwiązań, posunięta jest tak daleko, że nie występuje w Niemczech dla tego nowego gremium kierowniczego nawet jednakowa nazwa.

Stosunkowo częściej (75 szkół wyższych) używa się nazwy rada szkoły wyższej (Hochschulrat). Na 19 uczelniach jest rada uniwersytecka (Universitätsrat). Kuratorium przyjęło się jako nazwa rady na 11 uczelniach. Ponadto występują jeszcze w nielicznych przypadkach takie nazwy, jak: krajowa rada szkoły wyższej (Landeshochschulrat), rada fundacji (Stiftungsrat), zarząd fundacji (Stiftungsvorstand), rada instytucji (Institutsrat), doradcza rada artystyczna szkoły wyższej (Kunsthochschulbeirat).

Warto zauważyć, że jedynie w dwóch przypadkach użyto nazwy rada nadzorcza (Aufsichtsrat) dla szkół wyższych. Być może dlatego, iż często wcześniej w dyskusjach nad radami uczelni powoływano się na analogię z radami nadzorczymi spółek prawa handlowego (Röbken 2013). Takie skojarzenia zbytnio utożsamiałyby szkoły wyższe z przedsiębiorstwami komercyjnymi. Nie można traktować rady nadzorczej spółki tak jak rady uczelni (Handbuch Hochschulmanagement 2018). A tego raczej nie oczekiwano na uczelniach.

Tabela 1. Nazwy rad uczelni w różnych krajach związkowych

\begin{tabular}{|l|l|}
\hline \multicolumn{1}{|c|}{ Nazwa } & \multicolumn{1}{c|}{ Kraj związkowy } \\
\hline Rada nadzorcza & Badenia-Wirtembergia \\
\hline Rada szkoły wyższej & $\begin{array}{l}\text { Badenia-Wirtembergia, Bawaria, Hamburg, Hessen, Meckleburg- } \\
\text {-Vorpommern, Dolna Saksonia, Pólnocna Westfalia, Nadrenia- } \\
\text {-Palatynat, Saksonia, Turyngia, Szlezwik-Holsztyn }\end{array}$ \\
\hline Kuratorium & Berlin, Saksonia-Anhalt \\
\hline Krajowa rada szkół wyższych & Brandenburgia \\
\hline Rada uniwersytecka & Badenia Wirtembergia, Saara \\
\hline Rada naukowa & Saara (Wyższa Szkoła Techniki i Gospodarki) \\
\hline
\end{tabular}

Źródło: opracowano na podstawie: Wende (2016).

\section{ROLA, FUNKCJE, ZADANIA I KOMPETENCJE RAD UCZELNI W NIEMCZECH}

Możliwości działania rad szkół wyższych, a więc ich rola, funkcje, zadania i kompetencje są w rozwiązaniach prawnych w poszczególnych krajach związkowych bardzo zróżnicowanie. Wprowadzenie rad do szkół wyższych miało na celu rozszerzenie i umocnienie bezpośrednich kontaktów uczelni z interesariuszami. Miały one stanowić pewnego rodzaju bufor pomiędzy 
społeczeństwem, władzą i gospodarką a społecznością akademicką. Chodziło o doprowadzenie do równowagi pomiędzy, z jednej strony, założeniami wzmocnionej dzięki reformie, autonomii szkół wyższych a ich społeczną odpowiedzialnością, z drugiej strony. Należy jednak podkreślić, że rady $w$ niemieckich szkołach wyższych nie są instytucjami reperzentującymi bezpośrednie interesy społeczeństwa. Zasiadający obecnie w radach członkowie znaleźli się w ich składzie nie jako reprezentacja określonych grup społecznych, lecz jako charyzmatyczne jednostki, delegowane do tych organów ze względu na osobowość.

\section{PODSTAWOWE FUNKCJE RAD}

Przy wielu różnicach w konkretnych rozwiązaniach ustawowych każdego kraju związkowego, można zasadniczo wyróżnić trzy podstawowe funkcje, które mogą sprawować rady w uczelniach (Behm i Müller 2010):

1. Strategiczne doradztwo. Rada w szkole wyższej powinna, biorąc pod uwagę wielopłaszczyznową perspektywę zdobywania wiedzy, umiejętności i doświadczenia swoich członków, mieć wpływ na ogólny strategiczny rozwój uczelni, służąc pomocą kierownictwu w ustalaniu planów strukturalnych oraz kierunków rozwoju;

2. Pomost w relacjach ze społeczeństwem. W licznych dyskusjach nad reformą szkół wyższych wskazywano na niezbyt dostateczne uwzględnienie społecznych potrzeb i interesów społeczeństwa. Stąd postulowana konieczność większego zaangażowanie uczelni w tym zakresie i uwzględniania jej społecznej odpowiedzialności. Pośrednikiem w komunikowaniu się szkół wyższych ze społeczeństwem powinny być rady uczelni.

3. Nadzór nad kierownictwem uczelni. Rada powinna sprawować nadzór nad działaniami kierownictwa uczelni (władz rektorskich) w zastępstwie państwa. Może to dotyczyć zarówno udziału rady w wyborach władz rektorskich, jak i kontroli podejmowanych przez nie decyzji, w tym finansowych, i przyjmowania rocznych sprawozdań.

\section{KOMPETENCJE DECYZYJNE}

Podział środków w organizacji, zmiany w strukturze organizacyjnej i wytyczanie ogólnych kierunków rozwojowych, należą do kompetencji rad uczelni (Hüther 2009). W szczególności do przedmiotowych decyzji należy ustalanie kryteriów przekazywania środków, konstrukcja planu budżetu, planowanie struktury organizacyjnej, wpływ na zmiany w kierunkach studiów. Nie wszystkie rady szkół wyższych zajmują się analizowaniem poszczególnych działań i wyrażaniem aprobaty dla przygotowanych przez kierownictwo uczelni decyzji przedmiotowych. W większości krajów związkowych działania rady sprowadzają się jedynie do zatwierdzania decyzji w zakresie strategicznego rozwoju.

Najważniejszymi decyzjami personalnymi są wybór i odwoływanie władz rektorskich. Rady uczelni uczestniczą w podejmowaniu decyzji w zależności od rozwiązań występujących w poszczególnych landach. Dotyczy to wspólnego wyboru kierownictwa szkół wyższych wraz z senatem, proponowania kandydatów do władz albo samodzielnego wyboru władz uczelni. W niektórych krajach związkowych nie przewidziano udziału rad w powoływaniu bądź odwoływaniu rektora (na przykład: Mecklemburgia-Pomorze Przednie, Saksonia-Anhalt) (Linde 2016). 
W zdecydowanej większości uregulowań prawnych w poszczególnych landach radom przypisano jednak kompetencje zarówno w obszarze przedmiotowym, jak i personalnym (Linde 2016).

\section{SKŁAD RADY I ORGANIZACJA PRACY}

Kompetencje rad szkół wyższych nie są jedynymi czynnikami, na podstawie których można oceniać ich znaczenie. Innym czynnikiem jest skład tego gremium. Członkowie rad w szkołach wyższych z założenia mieli za zadanie wnieść na uczelnie zewnętrzny punkt widzenia. Przy doborze przedstawicieli wchodzących w skład rady występują dwa modelowe rozwiązania. Rady uczelni wyższych mogą składać się wyłącznie z przedstawicieli spoza uczelni. Może też występować wariant, gdy gremium to składa się z przedstawicieli spoza szkoły wyższej wraz z pracownikami delegowanymi z danej uczelni (model dualny).

Pięć krajów związkowych (Hesja, Mecklemburgia-Pomorze Przednie), Saara, Saksonia, Anhalt, Szlezwik-Holsztyn przewidziały jedynie czysto zewnętrzną obsadę rad uczelnianych. Sześć landów przyjęło dualny model (Badenia-Wirtembergia, Bawaria, Berlin, Dolna Saksonia, Nadrenia-Palatynat i Saksonia). Trzy inne kraje związkowe (Hamburg, Nadrenia-Westfalia i Turyngia) pozostawiły swobodę wyboru modelu uczelniom. W Brandenburgii nie obowiązuje ustawowa regulacja rozstrzygająca o obsadzie rad.

W zależności od landu zróżnicowana jest liczba przedstawicieli zasiadających w radzie, a także udział w niej zewnętrznych członków. Szkoły publiczne, w zależności od kraju związkowego, mają zdefiniowaną obsadę i górną granicę liczby członków. Jak wynika z badań (Röbken 2013), w większości z nich rada liczy od 5 do 11 członków. Rada składająca się wyłącznie z przedstawicieli zewnętrznych liczyła przeważnie 7 członków, a gdy w gremium tym zasiadali zarówno delegaci z zewnątrz uczelni, jak też i pracownicy, liczyła średnio 9 osób (Houten 2014).

Procedury obsadzenia rad uczelni również nie są jednolite i różnią się w zależności od kraju związkowego. Jedynie $w$ dwóch $z$ nich występują identyczne przepisy regulujące sposób postępowania przy wyborze członków tych gremiów; są to Turyngia i Nadrenia Westfalia. W zasadzie można wyróżnić cztery podstawowe warianty doboru przedstawicieli wchodzących w skład rad uczelni (Hüther 2009). Pierwszy z nich dotyczy takiego sposobu postępowania, w którym do krajowej rady szkół wyższych, obejmującej swym zasięgiem Brandenburgię, wchodzą kandydaci mianowani przez premiera tego landu, na wniosek ministra nauki. Drugi wariant doboru kandydatów do rady uczelni opiera się na dwóch różnych procedurach. $Z$ jednej strony przedstawiciele władzy politycznej, a z drugiej strony, władzy akademickiej wyznaczają (każde z tych ciał osobno, samodzielnie i niezależnie) członków rady uczelni. Ten sposób procedowania obowiązuje w trzech krajach związkowych: Nadrenii-Palatynacie, w kraju Saary i Hamburgu. Przy czym w dwóch pierwszych większość w radach uczelni mają tzw. członkowie zewnętrzni, czyli spoza szkoły wyższej. W Nadrenii-Palatynacie 5 członków mianuje minister szkolnictwa wyższego, pozostałych 5 wybiera senat uczelni większością 2/3 głosów. Większość głosów dla zewnętrznych przedstawicieli w głosowaniu rady uczelni zapewnia głos przewodniczącego, który należy do grupy tzw. 
zewnętrznej i w sytuacji patowej od niego zależy decyzja ostateczna. W kraju Saary rząd krajowy i senat szkoły wyższej wybierają po trzech członków rady uczelni. Siódmym członkiem rady jest nominat ministra, pełniący funkcję przewodniczącego.

Ministerstwo nauki ma niebezpośredni wpływ na zapewnienie większości w głosowaniach rad uczelni. W Hamburgu wyboru dokonują członkowie hamburskiego senatu, reprezentujący władzę landu oraz senatu danej szkoły wyższej w równych proporcjach - po 2 lub 4 osoby każda ze stron. Specyficzne dla tej procedury jest to, że powołani już członkowie wybierają do rady dodatkową osobę. Trzeci wariant wyboru członków rad uczelni opiera się na zgodnej opinii osób biorących udział w wyborach. Władze polityczne i akademickie muszą dojść za każdym razem do konsensusu w sprawie kandydatów do rad uczelni. Takie procedury wyboru występują w: Nadrenii-Westfalii, Turyngii, Badenii-Wirttembergii, Dolnej Saksonii i Bawarii. W czwartym wariancie doboru kandydatów na członków rady uczelni stosuje się czysto wewnętrzne dla danej szkoły wyższej procedury. Przypadek taki ma miejsce w 3 krajach związkowych: Mecklemburgii-Pomorzu Przednim, Saksonii-Anhalt i Hesji. Różnice biorą się stąd, że w dwóch pierwszych obsady dokonuje organ kolegialny (senat lub konsylium), w Hesji zaś prezydium uczelni.

Udział kobiet w radach uczelni w 2003 r., w którym po raz pierwszy odnotowano ten fakt, wynosił średnio 20\%; w 2016 r. osiągnął przeciętny poziom wynoszący 35\% (Löther 2017). Pomiędzy poszczególnymi krajami związkowymi występują w tym zakresie duże różnice. Rozpiętość udziału kobiet w radach zawiera się w przedziale od 15,2\% (Saksonia-Anhalt) do $50 \%$ (Szlezwik-Holsztyn). W niektórych krajach wysoki stosunkowo udział kobiet jest wynikiem prawnych regulacji. W Dolnej Saksonii prawo o szkolnictwie wyższym przewiduje, że wśród 7 członków rady uczelni powinny znaleźć się co najmniej 3 osoby kobiety. Podobne rozwiązanie występuje w Szlezwiku-Holsztynie. Ustawy wielu innych krajów związkowych przewidują ogólnie odpowiednią reprezentację kobiet lub parytetową ze względu na płeć obsadę rady, nie podając jednak konkretnych wskazań. Udział kobiet w radach uczelni, w zależności od ich typów, różni się także znacznie. W wyższych szkołach artystycznych jest to średnio $36 \%$, na uniwersytetach - prawie $45 \%$, a w wyższych szkołach zawodowych - tylko $31,8 \%$. Jednakże warto odnotować, że we wszystkich typach szkół wyższych udział kobiet gremium rady wzrósł. Krajowa rada uczelni w Brandenburgii liczy ponad 40\% kobiet w swoim składzie. Liczba szkół wyższych, w których tylko mężczyźni są reprezentowani w radach, spadła z 18 w 2015 r. do 14 w 2016 r. W 35 szkołach (11,3\%) w radach uczelni jest więcej kobiet niż mężczyzn (w 2014 r. było tak w 24 szkołach wyższych).

W Bawarii w posiedzeniach rad uczelni biorą udział przedstawiciele ministerstwa, lecz bez prawa głosu. Nie sprawdziła się teza, że rady uczelni będą „rzecznikami społeczeństwa”. Idea, aby w składzie rad uczelni znaleźli się przedstawiciele społeczeństwa, nie jest szczególnie zauważalna. Więcej niż połowę wszystkich członków rad uczelni stanowią przedstawiciele nauki, 1/3 - menedżerowie przedsiębiorstw (Röbken 2013). O tym, która z tych grup dominuje, zależy w danym przypadku profil szkoły. Reprezentujący gospodarkę kraju menedżerowie reprezentują stanowiska od prezesów koncernów, których akcje wchodzą w skład indeksu DAX, aż po kierowników średnich i małych przedsiębiorstw. Z tej grupy pochodzą w większości przewodniczący rad. Były prezes Deutsche Banku Rolf Breuer żądał przed kilkoma laty nawet zakazu uczestniczenia menedżerów w radach uczelni (Gillmann 2010), uważając, iż są oni zbyt obciążeni pracą zawodową. 
Spośród pozostałych członków rad uczelni największy udział mają politycy (8\%). Członkowie z obszaru kultury i sztuki, reprezentanci organizacji społecznych i związków zawodowych, fundacji czy kościołów, stanowią marginalną mniejszość. Rady uczelni miały dotychczas spore problemy w pełnieniu szczególnie funkcji kontrolnych. Członkowie tych gremiów spotykają się średnio 4 razy do roku (Heinze 2013). Tylko 30\% rad uczelni posiada samodzielnie funkcjonujące biura wspierające ich działania, pozostałe opierają się na informacjach $\mathrm{i}$ danych otrzymywanych $\mathrm{z}$ rektoratów. Istnieje zatem niebezpieczeństwo powstania asymetrii informacyjnej i w konsekwencji problemu agencji z hazardem moralnym w tle, który kierownictwo uczelni może wykorzystać, dbając o własne interesy. Dlatego w różnych landach i szkołach wyższych toczą się spory o to, czy rady uczelni nie powinny w swoich szeregach mieć członka zatrudnionego w tej szkole, aby otrzymywać niezależne od rektora informacje (Ziegele 2009). Z kolei całkowita zewnętrzna obsada rady uczelni ułatwia wiele działań i likwiduje wiele konfliktów wewnętrznych. Jak wygląda konflikt, można było zaobserwować na Uniwersytecie w Lipsku w 2015 r. (Semsrott 2015). Nie można było przez dłuższy czas wybrać ponownie rektora uczelni z partyjno-politycznych powodów. Rektor blisko związana z SPD krytycznie wypowiadała się o sposobie rządzenia landem przez partie CDU, do której należało kilku członków rady uczelni.

Jak wynika z badań (Müller 2014), istotną rolę w pracach rad uczelni odgrywają jej przewodniczący. Swoją działalność wykonują honorowo i poświęcają tym czynnościom przeciętnie 19 dni w roku. $Z$ tego $2 / 3$ czasu przypada na posiedzenia i kontakty z kierownictwem uczelni. Niektórzy spotykają się także z członkami senatu i ze studentami. Ich główne zadania to: współudział w pracach nad strategią szkoły wyższej (ustalenie celów, plany rozwojowe), doradzanie kierownictwu i funkcje nadzorcze. Poszukiwaniem sponsorów dla uczelni zajmuje się tylko niewielka liczba przewodniczących rad.

Działalność członków w radach uczelni ma także charakter honorowy. Członkowie nie otrzymują zatem wynagrodzenia. W niektórych landach prawo zezwala na ubieganie się o zwrot poniesionych kosztów, na przykład kosztów podróży.

Zdarzają się jednak także przypadki „niegospodarności” rad. Takie wnioski zamieściła Najwyższa Izba Kontroli Szlezwiku-Holsztyna w swoim sprawozdaniu w 2013 roku, przedstawiając wydatki rady na biesiady.

\section{WNIOSKI}

W dyskusjach na temat rad uczelni w Niemczech wyraźnie podkreślano, że głównym powodem ich wprowadzenia do szkół wyższych była chęć uwzględnienia społecznej perspektywy, profesjonalizacji menedżerskiej kierownictwa uczelni oraz zastosowania doskonalszych narzędzi do budowy strategii uniwersytetów. Trzeba jednak stwierdzić, że rady na niemieckich uczelniach nie są organami, które w sposób bezpośredni reprezentują społeczne interesy obywateli.

Instrumenty, jakimi posługują się w swojej pracy rady uczelni, są jeszcze stosunkowo słabo zbadane (Kretek 2012). Badania wykazały, że wyidealizowany obraz NPM w niemieckim systemie szkolnictwa wyższego wprowadzono niezbyt konsekwentnie. Krytycy systemu rad 
uczelni widzą w nich narzędzie do neoliberalnych przekształceń szkół wyższych w kierunku komercjalizacji. Istnieją też obawy, że mogą się one przyczynić do oddemokratyzowania szkół wyższych. Poddaje się w wątpliwość ich demokratyczną legitymizację.

Kontrowersje wzbudza zwłaszcza obecność w radach uczelni osób z nimi nie związanych, podejmujących decyzje, za które nie ponoszą odpowiedzialności, gdyż ich konsekwencji sami nie odczuwają.

Obsada rad uczelni, zgodnie z parytetem, zagraża trwałości uniwersyteckiej samorządności, ponieważ oznacza infiltrację szkolnictwa wyższego przez prywatne grupy interesów. Istnieją więc obawy, że zamiast tak bardzo oczekiwanej więzi szkół wyższych ze społeczeństwem staną się one raczej uczelniami kooperującymi z podmiotami gospodarczymi. Szkoły wyższe nie są przedsiębiorstwami. Mają one poprzez badania naukowe i dydaktykę w istotny sposób wpływać na demokratyczny i społeczny rozwój państwa.

\section{PIŚMIENNICTWO}

Behm B., Müller U. 2010. Erfolgsfaktoren für Hochschulräte. Handbuch Hoschsulräte: Denkanstöße und Erfolgsfaktoren für die Praxis. Essen, 16-105.

Bogumil J., Heinze R.G., Grohs S., Gerber S. 2007. Hochschulräte als neues Steurungselement? Eine empirische Analyse der Miglieder und Aufgabenbereiche, Abschlussbericht der Kurzstudie. www.boeckler.de

Borgwardt A. 2013. Hochschulräte und Hochschulsteuerung. Berlin, Zwischen Beratung und Kontrolle.

Gillman B. 2010. Die unkontrollierte Marcht der Manager an den Unis. Handelsblat. 10.09.

Handbuch Hochschulmanagement. 2018. Red. V. Breithecker, U. Lichfeltt, J. Radde. Berlin, ESV.

Heinze R.G. 2013. Hochschulräte als neues Steuerungsinstrument an Hochschulen. Hochschulräte und Hochschulsteurung. Berlin, FES,15-27.

Hüther. 2009. Hochschulräte als Steureungsakteure? Beiträge zur Hochschulforschung, 50-73.

Kretek P.M., Dahgsic Z. 2012. Hochschulräte in der Universitäts - Governance - Was bestimmt ihre Rolle und Wirkmächtigkeit? Wiesbaden VS, Hochschule als Organisation, 113-129.

Lange S. 2010. Hochschulräte, in: Handbuchg Wissenschaftspolitik. Red. S. Dagmar at. al. Wiesbaden, 347-360.

Linda J., Jörg B., Heinze R.G. 2016. Hochschulräte als nenes Steurungsinstrument von Universitäten? Eine empirische Analyse ihren Wirkungsweise. Zeitschrift für Public Policy, Recht und Management, Heft 1, 203-225.

Löther A. 2017. Geschleterspezifische Daten zur Besetzung von Hochschulräten und ähnlichen Gremien. Köln, GESIS.

Müller U. 2014. Wie Hochschulratsvorsitzende ihre Rolle wahrnehmen. Gütersloh, CHE.

Münch R. 2011. Akademischer Kapitalismus Ũber die politische Ökonomie der Hochschulreform. Frankfurt/M.

Röbken H., Schütz M. 2014. Hochschulräte. die Hochschule 2, 96-107.

Schröter E. 2011. New Public Management. Handbuch zur Verwaltungsreform, Wiesbaden, VS, 113129.

Semsrott A. 2015. Diener zweier Herren. www.correctiv.org

Winde M., Müller U. 2016. Hochschulräte in Deutschland - nicht unumstritten, aber unetbehrlich, KAS.

Ziegele F. 2009. Handlungsmöglichkeiten und Erfogsfaktoren von Hochschulräten. www.checoncept.de 
Streszczenie. Celem niniejszego artykułu jest próba opisania roli i znaczenia rad uczelnianych w niemieckim systemie szkolnictwa wyższego. Rady uczelni funkcjonują w Niemczech dopiero od dwudziestu lat i narzędzia, jakimi się posługują są jeszcze stosunkowo słabo zbadane. Członkowie rad uczelni widzą swoje funkcje zasadniczo w trzech wymiarach: strategicznym doradztwie dla kierownictwa uczelni, pomoście łączącym szkoły wyższe ze społeczeństwem oraz nadzorowaniu zarządzających uczelnią. Duże znaczenie dla przyszłej pracy rad mają procedury doboru jej członków. 
